\title{
EXTRAMEDULLARY INVOLVEMENT OF LYMPH NODES IN MULTIPLE MYELOMA
}

\author{
Zeljko Todorovic ${ }^{1,6}$, Milena Jovanovic ${ }^{4}$, Dusan Todorovic ${ }^{2}$, Anita Ivosevic1, Marina Markovic ${ }^{1}$, Drakce Radovanovic ${ }^{3,5}$, \\ Danijela Jovanovic ${ }^{1,6}$, Vesna Cemerikic ${ }^{7}$, Predrag Djurdjevic ${ }^{1,6}$ \\ ${ }^{1}$ Department of Internal medicine, Faculty of Medical Sciences, University of Kragujevac, Serbia \\ ${ }^{2}$ Department of Ophthalmology, Faculty of Medical Sciences, University of Kragujevac, Serbia \\ ${ }^{3}$ Department of Surgery, Faculty of Medical Sciences, University of Kragujevac, Serbia \\ ${ }^{4}$ Center of Nephrology and Dialysis, Clinic for Urology and Nephrology, Clinical Center "Kragujevac", Serbia \\ ${ }^{5}$ Surgical Clinic, Clinical Center "Kragujevac", Serbia \\ ${ }^{6}$ Clinic for Haematology, Clinical Center "Kragujevac”, Serbia \\ ${ }^{7}$ BEOlab, Belgrade \\ EISTRAMEDULARNA ZAHVAĆENOST LIMFNIH Č VOROVA \\ U MULTIPLOM MIJELOMU

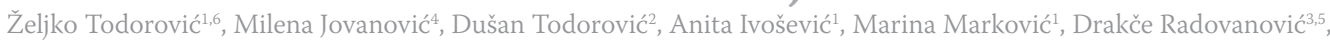 \\ Danijela Jovanovićc ${ }^{1,6}$, Vesna Cemerikic ${ }^{7}$, Predrag Đurđević ${ }^{1,6}$ \\ ${ }^{1}$ Katedra za internu medicinu,Fakultet medicinskih nauka, Univerzitet u Kragujevcu, Srbija \\ ${ }^{2}$ Katedra za oftamologiju, Fakultet medicinskih nauka, Univerzitet u Kragujevcu, Srbija \\ ${ }^{3}$ Katedra za hirurgiju, Fakultet medicinskih nauka, Univerzitet u Kragujevcu, Srbija \\ ${ }^{4}$ Centar za nefrologiju i dijalizu, Klinički centra "Kragujevac", Srbija \\ ${ }^{5}$ Klinika za hirurgiju, Klinički centra "Kragujevac", Srbija \\ ${ }^{6}$ Klinika za hematologiju, Klinički centra "Kragujevac", Srbija
}

Received / Primljen: 20. 06. 2016.

\begin{abstract}
Myeloma multiplex is a malignant disease of bone marrow plasma cells. It is usually confined to the bone marrow, but in rare cases, patients can develop extramedullary disease. The involvement of lymph nodes is rare and can be a diagnostic challenge.

Here, we describe a 36-year-old male patient who presented with abdominal pain and discomfort initially. An abdominal ultrasound followed by computed tomography (CT) revealed retroperitoneal and mesenteric lymph node enlargement. Biopsies of the abdominal lymph node and infiltrated colon showed a plasma cell infiltrate positive for CD79 , CD38, CD138, kappa light chain and VEGF2. Multiple myeloma with extramedullary localization was diagnosed. After six cycles of chemotherapy consisting of doxorubicin, dexamethasone and thalidomide followed by autologous haematopoietic cell transplantation, the patient achieved complete remission. Specifically, a CT scan after therapy showed enlarged lymph nodes in the abdomen, but PET CT scans did not detect any metabolically active foci. Three years after the completion of therapy, the patient remains in remission.

This case illustrates a rare presentation of extramedullary myeloma involving the abdominal lymph nodes, which could have been potentially mistaken for a lymphoid malignancy.
\end{abstract}

Keywords: multiple myeloma, extramedullary disease, lymph nodes, thalidomide

\section{SAŽETAK}

Multipli mijelom je maligna bolest plazmocita kostne srži. Obično je ograničen na kostnu srž, ali u retkim slučajevima kod pacijenata se može javiti ektramedularna lokalizacija bolesti. Zahvaćenost limfnh čvorova je retko i može predstavljati dijagnostički izazov.

Prikazali smo pacijena starog 36 godina, muškog pola koji je imao inicijalne tegobe $u$ vidu nelagodnosti $i$ bola $u$ abdomenu. Ultrazvuk $i$ kompjuterizovana tomografija abdomena pokazali su uvećanje retroperitonealnih I mezenterijalnih limfnih čvorova. Biopsija abdominalnog limfnog čvora i zahvaćenog dela debelog creva pokazala je infiltraciju plazmocitima pozitivnim na CD79 $\alpha, C D 38, C D 138$, kappa $i$ VEGF2 i pacijentu je postavljena dijagnoza multiplog mijeloma sa ekstramedularnom lokalizacijom. Pacijent je primio šest ciklusa hemioterapije sa doksorubicinom, deksametazonom i talidomidom nakon čega mu je uradena autologa transplantacija matičnih ćelija hematopoeze posle čega je registrovana kompletna remisija bolesti. Naime, na CT snimcima registrovani su uvećani limfni čvorovi u abdomenu, ali PET CT snimci nisu detektovali postojanje metabolički aktivnih fokusa.

Ovaj prikaz slučaja ilustruje retku prezentaciju ekstramedularnog mijeloma u abdominalnim limfnim čvorovima koji potencijalno može biti pogrešno protumačen kao limfoidna neoplazma.

Ključne reči: multpli mijelom, ekstramedularna lokalizacija bolesti, limfni čvorovi, talidomid
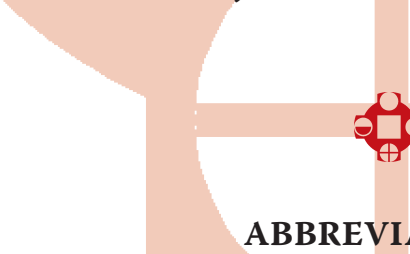

\section{ABBREVIATIONS}

MM: myeloma multiplex EMD: extramedullary disease 


\section{INTRODUCTION}

Myeloma multiplex (MM) is characterized by proliferation of malignant plasma cells. MM represents 13\% of all haematologic malignancies (1). Although it usually is confined to the bone marrow and surrounding bones, some patients develop extramedullary disease (EMD) in the form of soft tissue plasmacytomas. Local growth of MM within the bone marrow combined with direct spreading of the disease into the soft tissue surrounding the involved bones is the main mechanism of EMD development. Haematogenous metastatic spreading is the second, not so common mechanism of EMD development (2). Haematogenous spreading usually involves skin, liver, breast, or kidney (3) and in rare cases, lymph nodes (less than $1 \%$ of all EMD) (4). Here, we present the case of a patient with EMD involving the retroperitoneal and mesenteric lymph nodes at the time of MM diagnosis.

\section{CASE REPORT}

A previously healthy 36 -year-old man initially presented with abdominal pain and discomfort reported to have been occurring over the previous two months. Ultrasound revealed abdominal lymphadenopathy, and the patient was referred to the Hematology Department of Clinical Centre in Kragujevac with suspicion of a lymphoproliferative disease. Abdominal computed tomography showed mesenteric and retroperitoneal lymphadenopathy (the largest lymph node was $57 \mathrm{~mm}$ in diameter) without the formation of a conglomerate mass (Figure 1). Superficial lymph nodes were not palpable. The patient's haemoglobin was $8.3 \mathrm{~g} / 100 \mathrm{ml}$; white blood cell and platelets counts were 5.100 and 213.000 per cubic millimetre, respectively; and the erythrocyte sedimentation rate was $104 \mathrm{~mm} / \mathrm{h}$. His serum lactate-dehydrogenase level was elevated at $331 \mathrm{U} / \mathrm{L}$ (normal range: 94-250 U/L) as was his serum globulin at
$42 \mathrm{~g} / \mathrm{l}$ (normal range: $20-35 \mathrm{~g} / \mathrm{l}$ ); other values for biochemical analyses and parameters of haemostasis were within the normal range. Tests for HIV (human immunodeficiency virus) and $\mathrm{HCV}$ (hepatitis $\mathrm{C}$ virus) antibodies and HBV (hepatitis B virus) antigen were negative. Explorative laparotomy was performed, and biopsies of the abdominal lymph node and infiltrated colon were taken. Histological examination of the specimens revealed diffuse infiltration of the lymph node and colon with regular plasma cells, which were positive for CD79 $\alpha, C D 38, C D 138$, kappa light chain and VEGF2 (Figure 2). A bone marrow biopsy showed a slightly hypercellular marrow with $20-30 \%$ CD38+, CD138+, MUM-1+ plasma-cells. Serum protein electrophoresis with immunofixation identified an immunoglobulin G kappa monoclonal gammopathy (monoclonal spike [M-spike]: $2.5 \mathrm{~g} / \mathrm{dL}$ ) and a free kappa protein band. The serum kappa free light chain was elevated at $9361 \mathrm{mg} / \mathrm{L}$ (normal range: 5.71-26.3 mg/L), with the serum lambda free light chain within normal range. The beta- 2 microglobulin level was $3.72 \mathrm{mg} / \mathrm{L}$ (normal range: 0.7-1.8 $\mathrm{mg} / \mathrm{L}$ ). Any bone destruction could not be detected by $\mathrm{X}$-ray examination. Therefore, the patient was diagnosed with multiple myeloma with extramedullary localization in the colon and abdominal and retroperitoneal lymph nodes, corresponding to clinical stage IIA in the Durie \& Salmon staging system and clinical stage II in the International Staging System of myeloma. The patient was treated with six cycles of chemotherapy consisting of doxorubicin (17 $\mathrm{mg}$ days $1-4$ ), dexamethasone (40 mg days 1-4), and thalidomide (100 mg daily), followed by high doses of melphalan with autologous haematopoietic cell transplantation. Bone marrow biopsy after treatment did not show any signs of disease, and paraproteins were not detected by serum protein electrophoresis. A CT scan showed enlarged lymph nodes in the abdomen, but PET CT scans did not detect any metabolically active foci. As such, complete remission was achieved. Three years after the completion of therapy, the patient remained in complete remission.
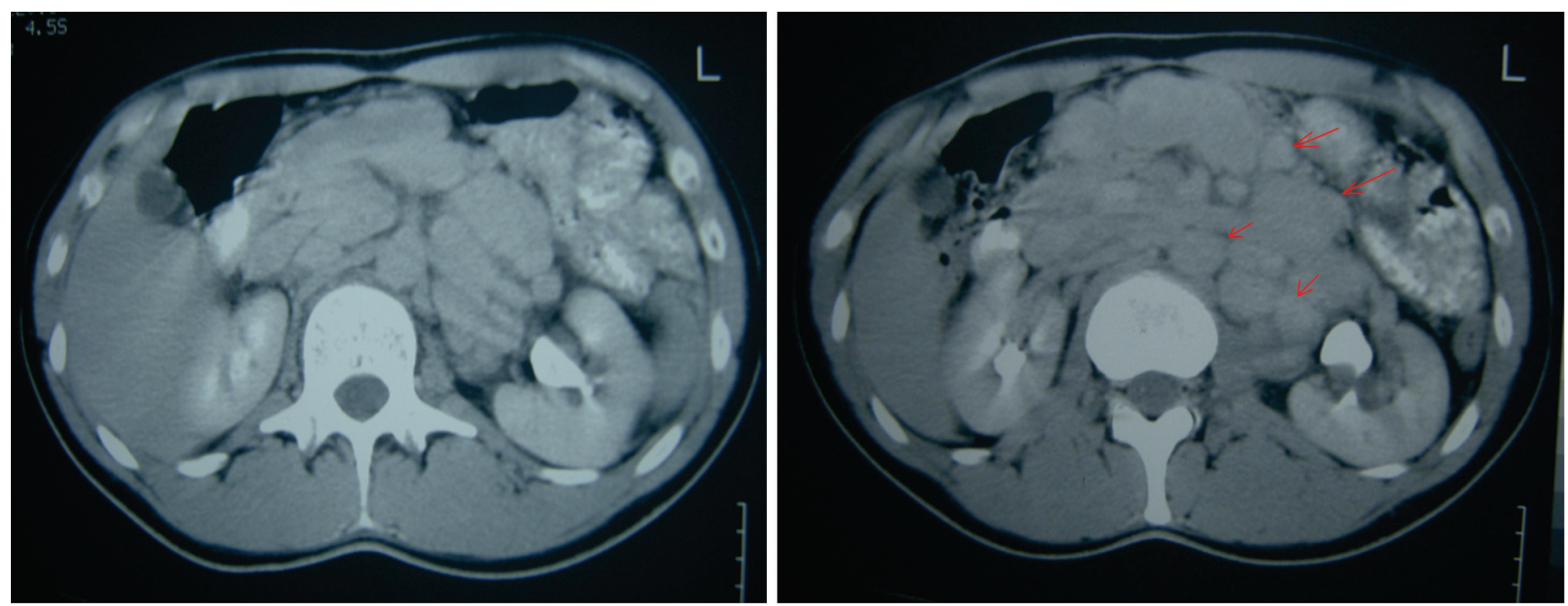

Figure 1. Abdominal computed tomography (CT). CT scans showing massive abdominal and retroperitoneal lymphadenopathy. 

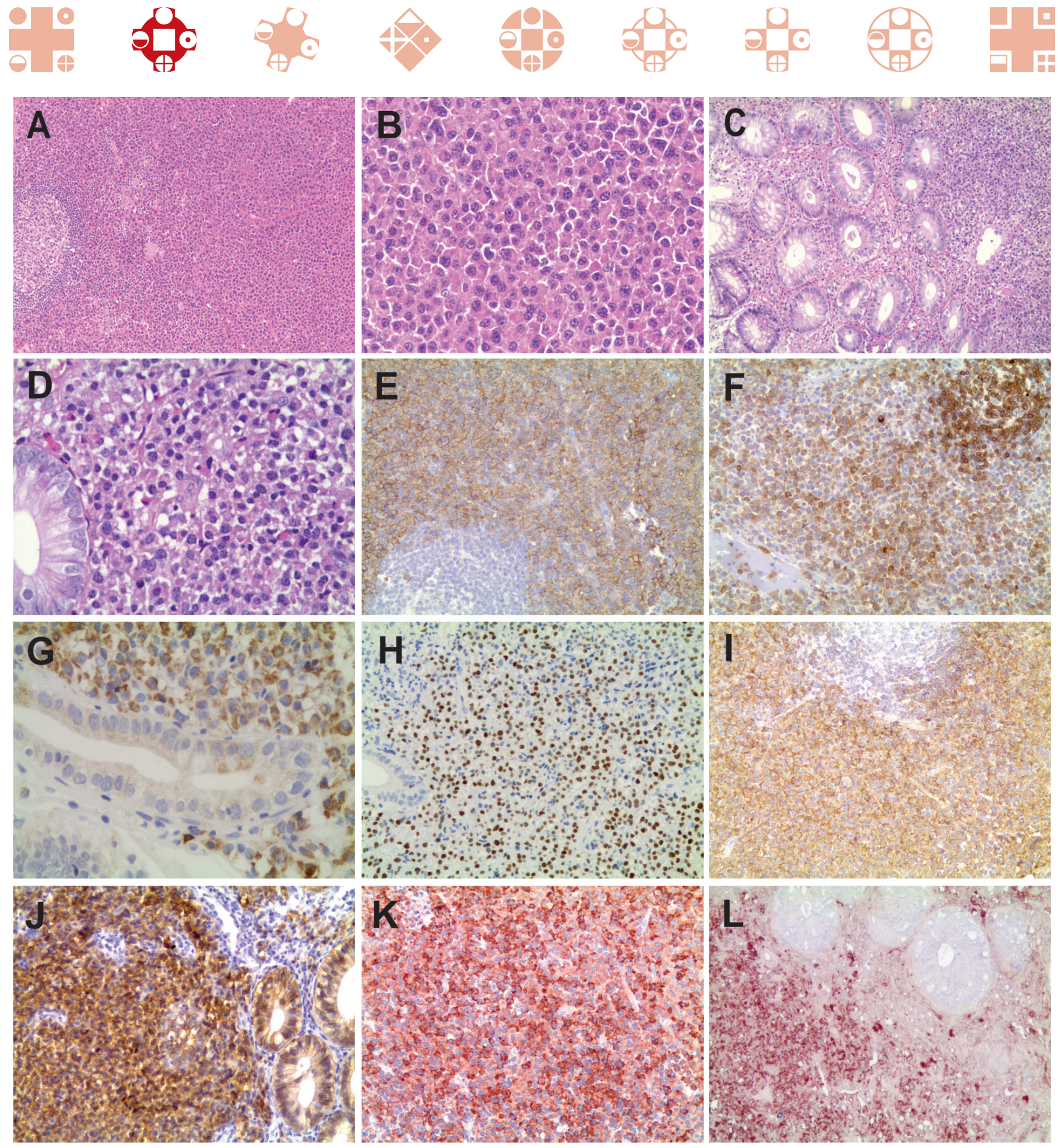

Figure 2. Histological and immunohistochemical examination of the abdominal lymph node and infiltrated colon. Haematoxylin and Eosin staining showing diffuse infiltration of the lymph node $(A, B)$ and colon $(C, D)$ with regular plasma cells. By immunohistochemistry, plasma cells were positive for CD38 (E), CD79 $\alpha$ (F, G), MUM-1 (H), CD138 (I, J), and kappa light chain (K, L).

\section{DISCUSSION}

The incidence of EMD seems to have increased over recent years. At the time of the diagnosis, $7-18 \%$ of patients with MM had EMD according to different studies (5-8). An additional $6 \%$ to $20 \%$ of patients develop plasmacytomas later in the course of disease $(7,8)$. One explanation for this could be the more frequent use and availability of sensitive imaging techniques, such as magnetic resonance imaging, computed tomography, and occasionally positron emission tomography. Additionally, the prolonged survival of myeloma patients due to the introduction of novel agents, such as proteasome inhibitors and immune modulators, in treatment has increased the incidence of EMD (5).

The infiltration of lymph nodes by malignant plasma cells could occur as a result of primary lymph node plasmacytomas. These can be diagnosed only after the exclusion of primary bone marrow involvement (9), and would represent a rare localization of primary plasmacytomas. On the other hand, lymph nodes could be involved in the 
extramedullary spreading of myeloma (10). The extramedullary involvement of lymph nodes is not frequently detected in living patients $(3,11,12)$ but is discovered more often in autopsies (13). An explanation for this could be the absence of symptoms in most cases. The patient that we presented here had dyspepsia and occasionally gastric pain that together with a high value of $\mathrm{C}$-reactive protein and a high erythrocyte sedimentation rate led to further investigation, which revealed mesenteric and retroperitoneal lymphadenopathy, first by ultrasound and then with computed tomography, after which a diagnosis was established based on the results of the biopsies.

Our patient was treated with a thalidomide-based regimen in six cycles, followed by autologous haematopoietic cell transplantation, and complete remission was achieved. Studies have shown that extramedullary progression of MM is associated with a worse prognosis $(5,6)$. In fact, patients with EMD at the time of the diagnosis, despite a lower International Scoring System (ISS) score, have poorer outcome regardless of first-line treatment (14). For de novo EMD patients who are eligible for stem cell transplantation, a triplet induction therapy approach (bortezomiblenalidomide-dexamethasone) is suggested, followed by high-dose melphalan with autologous haematopoietic cell transplantation, triplet consolidation therapy (bortezomiblenalidomide-dexamethasone), and maintenance treatment consisting of at least lenalidomide (15). Using thalidomide in the treatment of patients with EMD is controversial. Rosinol et al showed that patients with EMD did not respond to therapy with single agent thalidomide (16), which correlates with other studies that showed EMD progression under thalidomide treatment, despite a good bone marrow response $(17,18)$. In contrast, some cases of EMD responded well to thalidomide and dexamethasone therapy $(19,20)$. Based on the patient's age, good cardiac ejection fraction, large tumour mass, and contraindications for using bortezomib and lenalidomide as first-line therapy, we started to treat the patient with a combination of thalidomide, dexamethasone and doxorubicin, followed by high doses of melphalan and autologous haematopoietic cell transplantation. Using this regimen, the patient achieved complete remission.

To conclude, extramedullary myeloma is a heterogeneous entity that affects almost $15 \%$ of MM patients during their overall disease course. The clinical presentation can be very unusual and efforts should be made to optimally detect extramedullary disease. PET-CT is an important tool at diagnosis and during follow-up. After the treatment of EMD, patients are still exceedingly poorly managed, which is particularly challenging. It is necessary to define innovative treatment strategies to improve the outcomes of this subgroup of myeloma patients.

\section{REFERENCES}

1. Raab M S, Podar K, Breitkreutz I et al. Multiple myeloma. Lancet 2009; 374:324 - 339.
2. Joan Bladé, Carlos Fernández de Larrea, Laura Rosiñol. Extramedullary involvement in multiple myeloma. Haematologica. 2012 Nov; 97(11): 1618-1619.

3. Bladé J, Fernández de Larrea C, Rosiñol L, Cibeira MT, Jimenez R, Powles R. SoftTissue plasmacytomas in multiple myeloma: incidence, mechanisms of extramedullary spread, and treatment approach. J Clin Oncol. 2011;29(28):3805-12.

4. Wu P, Davies FE, Boyd K, Thomas K, Dines S, Saso RM, Potter MN, Ethell ME, Shaw BE, Morgan GJ. The impact of extramedullary disease at presentation on the outcome of myeloma. Leuk Lymphoma. 2009 Feb;50(2):230-5.

5. Varettoni M, Corso A, Pica G, Mangiacavalli S, Pascutto $C$, Lazzarino $M$. Incidence, presenting features and outcome of extramedullary disease in multiple myeloma: longitudinal study on 1,003 consecutive patients. Ann Oncol. 2009;21(2):325-30.

6. Wu P, Davies FE, Boyd K, Thomas K, Dines S, Saso $\mathrm{RM}$, et al. The impact of extramedullary disease at presentation in outcome of myeloma. Leuk Lymphoma. 2009;50(2):230-5.

7. Bladé J, Lust J, Kyle RA. Immunoglobulin D multiple myeloma: presenting features, response to therapy, and survival in a series of 53 patients. J Clin Oncol. 1994;12(11):2398-404.

8. Bladé J, Kyle RA, Greipp PR. Presenting features and prognosis in 72 patients with multiple myeloma who were younger than 40 years. Br J Heamatol. 1996;93(2):345-51.

9. Soutar R, Lucraft H, Jackson G, Reece A, Bird J, et al. Guidelines on the diagnosis and management of solitary plasmacytoma of bone and solitary extramedullary plasmacytoma. Br J Haematol. 2004 Mar;124(6):717-26.

10. Menke DM1, Horny HP, Griesser H, Tiemann M, Katzmann JA, et al. Primary lymph node plasmacytomas (plasmacytic lymphomas). Am J Clin Pathol. 2001 Jan;115(1):119- 26.

11. Masood A, Hudhud KH, Hegazi A, Syed G. Mediastinal plasmacytoma with multiple myeloma presenting as a diagnostic dilemma. Cases J. 2008 Aug 21;1(1):116.

12. Miyazaki T, Kohno S, Sakamoto A, Komori K, Sasagawa I et al. A rare case of extramedullary plasmacytoma in the mediastinum. Intern Med. 1992 Dec;31(12):1363-5.

13. Kazama T, Ng CS, Giralt SA. Multiphasic CT and MRI appearances of extramedullary multiple myeloma involving the stomach, pancreas, and bladder. Clin Imaging. 2005 JulAug;29(4):263-5.

14. Aguado B, Iñigo B, Sastre JL, Oriol A. Extramedullary plasmacytomas in the context of multiple myeloma. Adv Ther. 2011 Nov;28 Suppl 7:7-13.

15. Touzeau C, Moreau P. How I treat extramedullary myeloma. Blood. 2016 Feb 25;127(8):971-6.

16. Rosin ol L, Cibeira MT, Blade' J, et al: Extramedullary multiple myeloma escapes the effect of thalidomide. Haematologica 89:832-836, 2004. 
17. Avigdor A, Raanani P, Levi I, et al: Extramedullary progression despite a good response in the bone marrow in patients treated with thalidomide for multiple myeloma. Leuk Lymphoma 42:683-687, 2001. 18. Myers B, Grimley C, Crouch D, et al: Lack of response to thalidomide in plasmacytomas. Br J Haematol 115:234, 2001.

19. Nakazato T, Suzuki K, Mihara A, et al. Refractory plasmablastic type myeloma with multiple extra- medullary plasmacytomas and massive myelomatous effusion: remarkable response with a combination of thalidomide and dexamethasone. Intern Med. 2009;48:1827-1832.

20. Gonzalez-Porras JR, Gonzalez M, Garcia-Sanz R, et al. Thalidomide in combination with cyclophosphamide and dexamethasone (thacydex) is effective in soft-tissue plasmacytomas. Br J Haematol. 2002;119:883-884. 